\title{
FEDERICO ZUCCARI Y LA COMPAÑÍA DE JESÚS
}

\author{
MACARENA MORALEJO \\ Univerisdad Autónoma de Madrid
}

\section{Resumen}

El objetivo de este artículo es dar a conocer los vínculos de Federico Zuccari con la Compañía de Jesús en la península italiana, dado que él fue uno de los primeros artistas convocados para participar en las empresas artísticas que se iniciaron en la década de 1560 en Roma.

\section{Palabras clave}

Federico Zuccari, Compañía de Jesús, Dante Alighieri, Cardenal Francisco de Toledo S.J., Santa Maria dell'Annunziata, Purgatorio, Orazio Zuccari.

\section{FEDERICO ZUCCARI AND THE COMPANY OF JESUS}

\section{Abstract}

The aim of this article is to give notice of Federico Zuccaris bondings with the Society of Jesus in the Italian Peninsula given that he was one of the first artists convoked to participate in the artistic companies which initiated at Rome in the decade of 1560.

\section{Keywords}

Federico Zuccari, Society of Jesus, Dante Alighieri, Cardenal Francisco de Toledo S.J., Santa Maria dell'Annunziata, Purgatory, Orazio Zuccari. 


\section{Introducción}

Los artistas y teólogos, y también los demás, deben tener estudio particular y quieto, para mejor y más largamente entender las cosas tratadas.

\section{Instituciones de la Compañía de Jesús, 1552}

La estrecha vinculación que Federico Zuccari (Sant'Angelo in Vado, 1539 - Ancona, 1609) mantuvo con la Compañía de Jesús a lo largo de su trayectoria como pintor no ha despertado el suficiente interés en la historiografía que se ha ocupado de los jesuitas en la Edad Moderna, así como en las monografías, artículos y otras publicaciones que se han detenido en la figura del artista ${ }^{1}$. La proyección de los jesuitas en los medios eclesiásticos ejerció una sugestiva influencia en el devenir personal -y también profesional- del pintor que incluso, tal y como desvelamos por primera vez en este artículo, presionó a uno de sus hijos varones, Orazio, para que entrase a formar parte de la institución religiosa y favoreciese así los intereses de su progenitor desde este ámbitoº ${ }^{2}$.

\section{La intervención de Federico Zuccari en la Iglesia de Santa María dell'Annunziata y su divulgación en el ámbito europeo}

La relación se inicio en una fecha muy temprana, respecto al periodo de mayor esplendor de la Compañía, en la primera parroquia que el Papado confió a la Orden de San Ignacio en el centro de Roma. Así, Federico Zuccari realizó una precoz intervención, la primera en solitario liberado de las directrices estéticas dictadas por su hermano mayor, en una de las capillas de la iglesia de Santa Maria dell'Annunzriata, entre 1566 y 1567. Nos referimos a un fresco, hoy desaparecido, cuyo programa iconográfico deslumbró a los contemporáneos por las innovaciones propuestas en la representación del tema La Anunciación, un tema en el que raramente se introducían variantes de relevancia. ${ }^{3}$ La elección del artista no era casual, se trataba del primer templo en el que los jesuitas iniciaron las funciones que, años más tarde,

1 Aquí citamos solo aquellas monografías, actas de congresos y exposiciones acerca de Federico Zuccari más relevantes en orden cronológico de publicación: KORTE W., Der Palazzo Zuccari in Rom. Sein Freskenschmuck und seine Geschichte, Leipzig, 1935; GERE J., Mostra dei disegni degli Zuccari (Taddeo, Federico Zuccari, e Raffaellino da Reggio), catálogo de la exposición, ed. Leo Olschki, Firenze, 1966; GERE J., Dessins de Taddeo et Federico Zuccaro, catalogo de la exposición, Réunion des Musées Nationaux, Paris, 1969 ; GERE J., Taddeo Zuccaro: His development studied in his drawings, ed. Faber and Faber, London, 1969; VOLKER A., Beziebungen zwischen Theorie und Praxis im Werk. Federico Zuccaros, Fakultät der Universität Wien, Wien, 1972; MUNDY J., Renaissance into Baroque: Italian Master Drawings by the Zuccari 1550-1600, Cambridge University Press. 1989; RICCI C., "Federico Zuccari e Dante", Catalogo della mostra a Pescara, Torre de' Passeri, 26 -Settembre- 30 de Novembre 1993, Milano, ed. Electa, 1993; WINNER M., - HEIKAMP D., Der Maler Federico Zuccari in römischer virtuoso van europäischen Ruhm. Akten des Internationalen Kongresses der Bibliotheca Hertziana, Rom und Florenz, 23-26 Februar, 1993; CLERI B., Per Taddeo e Federico Zuccari nelle Marche, Atti del Convegno, Sant'Angelo in Vado, 18 septiembre - 7 de noviembre, 1993, ed. Regione Marche ; Provincia di Pesaro e Urbino; Municipio di Sant'Angelo in Vado,1993; CLERI B., Federico Zuccari: Le idee, gli scritti, Actas del Congreso celebrado en Sant'Angelo in Vado, 28-30 de Octubre de 1994, ed. Electa, Milano, 1997; ACIDINI LUCHINAT C., Taddeo e Federico Zuccari, dos vols. Ed. Jandi Sapi,Milano, 1997; VEDDIGEN T., - BRUNNER B., Federico Zuccaro Kunst zwischen Ideal und Reform, ed. Istituto Svizzero di Roma, 2000; HERRMANN- FIORE K., Federico Zuccari: La pietà degli angeli, il prototipo riscoperto del fratello Taddeo e un'anatomia degli artisti, Roma, 2001; BROOKS J., Taddeo and Federico Zuccaro: artist-brothers in Renaissance Rome, Los Angeles, John Paul Getty Museum, 2007; BRUGEROLLES E., - GUILLET D., Di, segno, o : dessins de Taddeo et Federico Zuccari dans les collections de l'École Nationale Supérieure des Beaux-Arts, Paris 12 février - 4 mai 2007 ; Musée Fesch, Ajaccio, 15 juin - 2 septembre 2007; VV.AA., Federico Zuccari: Innocente e calunniato. Le vendette d'artista, Firenze, 2010

${ }^{2}$ El contrato matrimonial con Francesca Genga, madre de Orazio y del resto de hijos de la pareja, fue redactado en Urbino, pero rubricado en Roma el 22 de Mayo de 1578, mientras que la boda se celebró el 12 de Octubre de 1578 en Florencia. Véase KORTE W., op.cit., 1935, p.70, n.2; ACIDINI LUCHINAT C., op.cit., 1997, vol. I, p.121, n.157. Vincenzo Lanciarini y Francesco Cerasoli se ocuparon, a finales del siglo XIX y principios del XX, de los descendientes de Federico Zuccari en sus publicaciones pero no proporcionaron datos acerca de la actividad de Orazio como jesuita. Véase CERASOLI F., Federico Zuccari, la sua famiglia e le sue case, Roma, 1909; LANCIARINI V., «Dei pittori Taddeo e Federigo Zuccari di Sant'Angelo in Vado», en La Nuova Rivista Misena, 1893.

3 ㄴóase ACIDINI LUCHINAT C., op.cit., 1997, vol. I., pp.255-258. 
despertarían el interés de la alta sociedad romana, es decir, los sermones públicos y las celebraciones eucarísticas.

Esta parroquia protagonizó, por tanto, un papel decisivo, como centro de emanación del ideario ignaciano en Roma, una circunstancia que no pasó inadvertida años más tarde, con su destrucción a principios del siglo XVII, y la erección en el mismo solar de la iglesia de San Ignacio, coincidiendo con la canonización del vasco en el año 1622. A la importancia de este encargo pictórico, un verdadero reto para Federico Zuccari, habría que unir las tensiones derivadas al tener que enfrentarse en solitario, por primera vez en su vida, a una obra de tal magnitud. No podemos olvidar que su hermano mayor, Taddeo, responsable del taller familiar, había fallecido de manera inesperada nada más iniciar la obra, en el otoño del año 1566. ${ }^{4}$ El conjunto, que conocemos de forma fragmentaria, a través de copias y grabados de la época, demuestra que la ausencia de Taddeo significó un doloroso incentivo para Federico, que deseaba sentirse respaldado por una institución emergente, como la Compañía de Jesús, y anhelaba lograr un reconocimiento público para formar su propio taller.

Así, el fresco de La Anunciación, desaparecido casi en su totalidad, se conoce íntegramente gracias a los grabados que el propio pintor encargo a Cornelis Cort en $1570 \mathrm{y}$, con posterioridad a esta fecha, a Olgiato y a la familia Sadeler, una señal inequívoca de la publicidad que el propio Federico Zuccari concedió a esta primera experiencia en solitario ${ }^{5}$ Además, el artista se alejó del habitual tratamiento intimista de la escena descrita en el Nuevo Testamento para dotarla de un aparato teatral y de una grandiosidad que sólo se justifica a la luz de las conquistas en la recreación de los espacios arquitectónicos de la pintura renacentista.

El grado de intimidad que había vehiculado hasta entonces cualquier represent ación de la escena de La Anunciación fue alterado por Federico Zuccari con la aparición en la parte superior de Dios, representado como el Padre Eterno, que bendice acompañado de la paloma del Espíritu Santo que desciende hacia la esfera terrenal acompañada de un cortejo de ángeles. En la parte inferior de la representación situó a los profetas, dispuestos de izquierda a derecha en el siguiente orden: Moisés, Isaías y el rey David. ${ }^{6}$ El centro de la composición fue elegido para la representación neotestamentaria de la escena más importante, la de La Anunciación, mientras que La Virgen aparece flanqueada por las figuras de Salomón y Jeremías, quienes sostienen sendas inscripciones aludiendo a su papel como depositarios del anuncio profético de la venida del Mesías en los textos del Antiguo Testamento. La ruptura con la disposición tradicional del espacio y el tiempo aparece enfatizada a través de la contemplación de dos paisajes, el nocturno y el diurno, que deben identificarse con la simbología cristológica y mariológica muy divulgada en la época a través de las representaciones ilustradas, por

$4{ }^{4}$ El desamparo que se cernía sobre el artista, después del fallecimiento de su hermano mayor, fue descrito por un amigo de la familia en una misiva alegada por OTTAVIANO ZUCCARI a un manuscrito redactado por él mismo recientemente encontrado en la Biblioteca Apostólica Vaticana: Idea de' concetti politici, morali e cristiani. Para la carta véase BAV- SALA DE MANUSCRITOS-URB. LAT. 1657, fol.557v. El autor de la misiva manifestaba que los amigos de Taddeo no abandonarían a su hermano Federico en estos difíciles momentos. Datos sobre el hallazgo de esta carta en MORALEJO ORTEGA M., La teoría artística de Federico Zuccari: Antecedentes y repercusiones en la tratadistica moderna, tesis doctoral, Universidad

Pontificia Gregoriana - Universidad de Valladolid, 2008, parte V. Similares comentarios fueron realizados por Giorgio Vasari en su descripción de la vida de Taddeo Zuccari. Cfr., VASARI G., Le vite, Firenze, 1568 (ed. Milanesi, 1881, vol.VII, pp.142).

${ }^{5}$ Los grabados, y esta hipótesis no se han planteado, quizá incorporaron novedades iconográficas respecto a la pintura ideada por Federico Zuccari. Se desconocen también las razones que llevaron al grabador Cornelis Cort, el favorito del pintor, a dedicar el grabado al Cardenal Granvelle

$6 \quad{ }^{6}$ Moisés lleva una cartela con la siguiente didascalia: Prophetam de gente tua et de fratibus tuis sicut me suscitabit tibi Dominus Deus tuus. Deuter XVIII (Deuteronomio, 18); Isaías sostiene una inscripción análoga: Ecce virgo concipiet et pariet filium. Isa VII (Isaías, 7), mientras que el rey David sostiene unos versos del salmo 131: "De fructu ventris tui ponam super sedem tuam.Psal CXXXI" (Salmos, 131). Salomón aparece representado con la siguiente cartela: Veniat dilectus meus in hortum sum. Cant V (Cantar de los Cantares, 5) y Jeremías: "Creavit Dominus novum super terram: Femina circumdabit virum.I ere XXXI". (Jeremías, 31) Hageo, colocado en el último lugar, lleva una inscripción que reza: "Adhuc modicum et veniet desideratus cunctis gentibus. Agg.II". (Hageo, 2). 
ejemplo, de los textos para el rezo del Santo Rosario, tan famosos como el escrito por Alberto de Castellanos en el año 1566 con el título "Rosario de la Gloriosa Vergine Maria", entre otros. Por último, y ocupando un espacio destacado, en el fresco aparecían en los extremos las figuras de Adán y Eva, que sostienen una cartela, y que también aluden a los primeros moradores de El Paraíso.

El punto de origen de esta composición, a nuestro juicio, debe buscarse en el viaje que Federico Zuccari realizó, apenas tres años antes del inicio de esta obra, a la ciudad de Venecia, en donde fue acogido por el Cardenal Grimani y realizó algunas intervenciones de carácter artístico en solitario. Este periplo, que podría denominarse como su "viaje iniciático" le permitió ponerse en contacto con un ambiente cultural hasta entonces desconocido, así no podemos descartar la visita del pintor a la iglesia local de San Antonio Abad, un templo en el que se conservaba un magnífico políptico, ideado por Lorenzo Veneziano y Francesco Biassolo. La obra, denominada como "Políptico Lion" por la historiografía del arte posterior, fue creada para su instalación en el altar mayor de la iglesia en el año 1356, y es la primera documentada en la que aparece, no solo la emblemática escena de "La Anunciación" en la tabla central, sino también los profetas que habían anunciado la llegada del Mesías en el Antiguo Testamento. ${ }^{7}$ Esta hipótesis de trabajo, hasta ahora jamás comentada, cobra una nueva dimensión para nuestro estudio, puesto que posiblemente se trató de un importante reclamo visual e iconográfico para el artista.

En cualquier caso, el conjunto de la composición ideada por Federico Zuccari para la parroquia romana se conoce gracias a las series grabadas, dado que del origi nal solo se conserva un pequeño fragmento - muy escondido a los ojos de feligreses y turistas- en la iglesia romana de San Ignacio. Se trata de la imagen de La Virgen, que fue trasladada a un soporte más adecuado para su conservación que el fresco, mutilado prácticamente en su totalidad. ${ }^{8}$ La pérdida irreparable del resto de la composición no permite realizar un análisis completo del fragmento conservado, y sobre todo, no resulta sencillo determinar las dimensiones reales de la pintura mural ideada por el manierista, es decir, tal y como fue concebida por Federico Zuccari en la década de 1560.

El grado de invención y autonomía creativa del pintor, visible a través de los grabados de la obra, recoge el tratamiento exquisito de una escena coral muy influenciada por las premisas estéticas que habían vehiculado composiciones tan aplaudidas en la época como La Disputa del Sacramento de Rafael Sanzio, cuya divulgación a través de la estampa también benefició la multiplicación de copias y versiones más pequeñas -y menos ambiciosas- destinadas a ser adoptadas en el marco decorativo de algunas iglesias erigidas por la Compañía, e incluso en otros emplazamientos religiosos.

El maestro de Urbino constituía, en este sentido, un modelo a imitar por su talento, creatividad y la puesta en escena de una serie de valores teatrales de gran intensidad pictórica y religiosa, y posiblemente el artista albergó siempre el deseo de secundar algunos de los proyectos de su compatriota. El éxito alcanzado por Federico Zuccari con el fresco pintado para la iglesia de Santa Maria dell'Annunziata fue, evidentemente, menor al logrado por Rafael pero no puede infravalorarse. En este sentido, la historiografía del arte ha resaltado los dos óleos que pintaron dos artistas de la escuela Toscana, así como una pintura mural ideada para el Duomo de Carrara, y que se inspiraron directamente en la escena de La Anunciación pintada por Zuccari. ${ }^{9}$ El hallazgo de una nueva versión en fechas recientes, un óleo sobre lienzo de

\footnotetext{
${ }^{7}$ La obra se conserva en la Galería de la Academia de Venecia

${ }^{8}$ Véase la ficha de MORALEJO ORTEGA M., del único fragmento del que disponemos de La Anunciación de Federico Zuccari publicada en TAPIE A., (ed.,) Baroque, vision jésuite, ed. Sogomy, Paris, 2003, pp.178-179

${ }^{9}$ Una de las versiones se ha atribuido a Domenico Saccheta, la segunda versión, descrita por la profesora Acidini Luchinat en su monografía sobre los hermanos Zuccari, ha sido vinculada con la producción de Aurelio Lomi. Para la reproducción de estas pinturas y los dibujos preparatorios realizados por Federico Zuccari véase ACIDINI LUCHINAT C., op.cit. 1997, vol. I, pp. 255-257
} 
un seguidor de Federico Zuccari en el mercado del arte, ${ }^{10}$ confirma el alcance del modelo ideado por el italiano incluso en las inmediaciones de Roma. Así mismo, apenas se ha escrito sobre las versiones del fresco realizadas en la Península Ibérica, en especial por parte de la escuela andaluza de pintura, una circunstancia que solo fue posible a partir de la difusión de los grabados, y quizá, aunque esta última cuestión es solo una hipótesis, de alguno de los bocetos previos ideados por el italiano para la ejecución de la pintura mural.

A este respecto, y a modo de ejemplo ilustrativo, conviene mencionar el lienzo, creado posiblemente por Francisco Pacheco, y conservado a día de hoy en la residencia-museo del escritor Lope de Vega en Madrid, o la réplica en fresco del sevil lano Luis de Vargas, que con seguridad reprodujo la escena pintada por el italiano en la Catedral de Sevilla; extremo que, de confirmarse, constituiría la primera copia conocida - y también destruida- del fresco de Federico Zuccari. ${ }^{11}$

Francisco Pacheco reflexionó también por escrito acerca de la obra en el tratado de El arte de la pintura, e incluso demostró que había manejado algunos de los dibujos previos que el propio Federico realizó a modo de bocetos para la elaboración de la composición. ${ }^{12} \mathrm{El}$ reciente hallazgo de una versión de la misma obra por parte del jesuita Heinrich Pfeiffer, para la catedral de Puebla de los Ángeles en México ${ }^{13}$ confirma la inequívoca popularidad de la pintura mural ejecutada por Zuccari y la fama de las estampas ideadas por Cornelis Cort, Olgiato y Rafael Sadeler en España y en los territorios americanos.

La composición también suscitó la curiosidad de los teóricos del arte, Giorgio Vasari alabó la obra como un hito en la carrera profesional de los hermanos Zuccari, dando por hecho que la participación de Taddeo había sido mucho más importante de lo que, a priori, transmitió el propio Federico, si bien no podemos olvidar que el propio hermano menor

${ }^{10}$ Reproducimos la obra por primera vez en el marco de un estudio de este tipo en el aparato de imágenes de este artículo

11 Para las versiones hispánicas del fresco romano véase el articulo de BASSEGODA I HUGAS B., «Adicciones y complementos al catálogo de Francisco Pacheco», en Boletín del Museo e Instituto Camón Aznar, XXXI-XXXII, 1988, pp.151-176. El profesor Bassegoda aludió también a una versión del pintor flamenco Lombard vendida en Sotheby's en 1985. Sobre la discutida autoría de Francisco Pacheco de la copia conservada en el Museo Lope de Vega véase la opinión de NAVARRETE PRIETO B., La pintura andaluza del siglo XVII y sus fuentes grabadas, Alcalá de Henares, 2000, p.115, n.430. En el catálogo del museo dedicado a Lope de Vega la obra aparece, en cambio, atribuida a Eugenio Cajés.

${ }^{12}$ Francisco Pacheco y Federico Zuccari jamás se conocieron personalmente, a este respecto, conviene recordar que Pablo de Céspedes, amigo común de ambos, quizá informó al andaluz de la trayectoria del italiano e incluso pudo enseñarle o regalarle alguno de los dibujos que Federico Zuccari le proporcionó a su regreso a España. La presencia del sacerdote andaluz en Roma se ha podido fechar recientemente gracias a la publicación de los verbales de Compagnia di S. Guiseppe di Terrasanta, en donde su nombre aparece desde enero de 1572, la fecha de su entrada en la corporación. Desde 1573 ejerció funciones como secretario de la institución y posiblemente se mantuvo en el cargo hasta 1578, año en el que fue sustituido por Vittorio di Moxica. Para estas cuestiones véase TIBERIA V., La Compagnia di S. Guiseppe di Terrasanta nel XVI secolo, ed. M. Congedo, 2000. Datos sobre la residencia del cordobés en Roma, junto con bibliografía adicional sobre el tema en MORALEJO ORTEGA M., "Pablo de Céspedes: Amigos e interlocutores en Roma nuevos datos», en Anuario de Historia de la Iglesia Andaluza, 2010, pp. 227-240. Los dibujos del italiano adquirieron un valor añadido para Francisco Pacheco, puesto que éste defendió el modo en el que se había representado la escena de La Anunciación como la más correcta y respetuosa con las directrices emanadas por la Iglesia después del Concilio de Trento. Un análisis de los dibujos y su dispersión en los museos europeos en el artículo de KORTE W., «Verlorene Frühwerke des Federico Zuccari in Rom», en Mitteilungen des Kunsthistorischen Institut in Florenæ, 1919-1932, pp.520-529. Por desgracia, los dibujos que probablemente estudió Francisco Pacheco, conservados desde el siglo XIX en el Instituto Jovellanos de Gijón, fueron destruidos durante la última guerra civil española. El tema ha sido modernamente tratado por B. BASSEGODA I HUGAS en su edición crítica de El Arte de la Pintura escrita por Francisco Pacheco (ed. Cátedra en 1990). La dispersión de dibujos preparatorios del fresco en varias colecciones europeas y americanas ha sido descrita en varias ocasiones, véase a este respecto VV.AA. Italian drawings: Umbria, Roma, Naples, National Museum Stockholm, 1998, n 595 y con anteriodad véase SIRÉN O., Italienska handtekninger fran 1400 - och 1500- talen i Nationalmuseum, Stockholm, 1917, n 383

${ }^{13}$ Una reproducción de la pintura en el ensayo de PFEIFFER H. S. J., «L'iconografía dei gesuiti» en el volumen dirigido por SALE G. S.J., Sant'Ignazio e l'arte dei gesuiti, ed. Jaca Book, Milano, 2003, pp.169 y ss. 
transmitió al aretino los datos biográficos más sobresalientes de sus trayectorias. El testimonio de Vasari fue recogido -y ampliado significativamente- por Raffaello Borghini y Giovanni Baglione. Su aportación reviste gran interés porque ambos señalaron, además, que los jesuitas también habían encargado a Federico la representación de las escenas de La Natividad y La Circuncisión de Cristo, obras de las que no se tiene noticia de su ubicación desde la destrucción de la iglesia romana a principios del siglo XVII. ${ }^{14}$

La existencia de otros testimonios, quizá menos conocidos pero igualmente importantes para comprender el éxito logrado por el pintor en los ambientes académicos, son decisivos para redimensionar el interés que suscitó el fresco en el ambiente artístico europeo. Así, Karl Van Mander, Giulio Mancini o Vincenzo Giustiniani expresaron su admiración por los resultados y juzgaron la obra como un verdadero capolavoro e insuperable en la producción artística posterior de Federico Zuccari. ${ }^{15}$

El reciente hallazgo de un ribaldone manuscrito escrito a principios del siglo XVII por Ottaviano Zuccari, el primogénito de Federico Zuccari, en la Biblioteca Apostólica Vaticana, ${ }^{16}$ recoge una amplia variedad de noticias relacionadas con la producción literaria y artística del progenitor, y también el modo en el que su propia familia respaldó sus actuaciones en el marco de la pintura. Así, Ottaviano describió en uno de los folios del volumen la perfecta distribución de los once cielos - al hilo de la cosmografía de la época descrita por el Padre Clavio y otros jesuitas- e incidió especialmente en la composición del empireo, el punto de reunión de todos los personajes que su propio padre retrató en el fresco de La Anunciación entre santos y profetas. Así, la analogía entre el cielo empireo y la ciudad de Dios le permitió instaurar una paradigmática relación entre la visión divina -aquella que había vehiculado el proceso creativo de la pintura- y la recreación del mismo episodio en las fuentes literarias que, desde la escolástica, se habían ocupado del mismo tema:

[...] (Nel cielo empireo) si vede Christo sedente alla destra del Padre. Lo Spirito Santo che procede dal
Padre, e dal Filio, e la Gloriosissima Vergine Maria, Regina de gl'angeli, Imperatrice del Mondo,
monarca dell'Universo, e madre verissima dell'Omnipotente Iddio. E qui final-mente si vedono gl'angeli,

${ }^{14}$ Sobre los testimonios de estos tratadistas véase nuestra ficha en el catálogo de la exposición Baroque, vision jésuite, Paris, 2003, pp.178-179 que contiene la descripción del grabado de Cort y Sadeler. Reproducimos aquí la descripción de una fuente inédita manuscrita que ya fue señalada en la propia ficha de la obra. Se trata del manuscrito conservado en el Archivo de la Universidad Pontificia Gregoriana (APUG) titulado ORIGINE DEL COLLEGIO ROMANO E SUOI PROGRESSI, fol 27v, (...) "La tribuna della Chiesa è stata dipinta assai nobilmente, è stata incominciata la pittura da Taddeo Zuccaro, ma essendo questi morto è stata seguitata e compiuta da Federico Zuccaro suo fratello. Si rappresenta in quella la Vergine Annunziata dall'Angelo, vi sono attorno i Profeti: ciascuno de' quali tiene in mano una cartella, in cui vengono espresse le parole della Profezia, che aveva fatta circa il mistero dell'Incarnazione. Nella Pittura vi sono espressi il Padre Eterno, e lo Spirito Santo con una moltitudine grande di Angeli, che formano loro corona a corte. L'eccellenza del lavoro hà fatto che la Pittura si desse alla stampa in un bel rame. Ve ne sono sparse molte copie, delle quali ne resta qualcuna ancor presente (...). Una copia de este manuscrito, utilizado en otras ocasiones por los historiadores como fuente de datos para la historia del Collegio Romano, en el Archivio Romano Societatis Iesu (ARSI), Roma, vol.150

15 VAN MANDER K., Het Schilder Bock, Amsterdam, 1618, fol.110. Véase la edición en italiano Le vite degli illustri pittori fiamminghi, olandesi e tedeschi / introduzione, traduzione e apparato critico di Ricardo de Mambro Santos., ed. Sant'Oreste, Apeiron, Roma, 2000; GIUSTINIANI V., Discorsi sulle arti e sui mestieri, ed. de BANTI A., Sansoni, Firenze ,1981, pp.44-45; MANCINI G., Consideraz̧ioni sulla pittura, ed. L. SALERNO, Roma, 19561957; véase la tesis doctoral de BOWCUTT BUTLER T., Giulio Mancini’s “Consideratins on paintings", Cleveland, Ohio, Case Western University, Phil. Diss. 1973.

16 AV - Sala de Manuscritos - Urb. Lat.1657- Anni 1615-1618 chart.mm. 245 x 174 ff. 1-708. Véase también la versión impresa, con variantes, del manuscrito de Ottaviano Zuccari: L'idea de concetti politici, morali e christiani, Bologna, 1628. Sobre la identificación del manuscrito, las razones de su actual ubicación y los contenidos propuestos véase MORALEJO ORTEGA M., Marginalidad en el ámbito de la literatura artística. La figura de Ottaviano Zuccari (1579-1629) en Actas del XVII Congreso CEHA, Santiago de Compostela, Septiembre, 2010, (en prensa); IDEM., Nuevos datos acerca de los viajes de Federico Zuccari (1539?-1609) por las cortes europeas: Las aportaciones inéditas de Ottaviano Zuccari, primogénito del artista, Actas del Congreso "El arte y el viaje", CSIC, Noviembre 2010, ed. Madrid, CSIC, 2012, pp. 17-33 


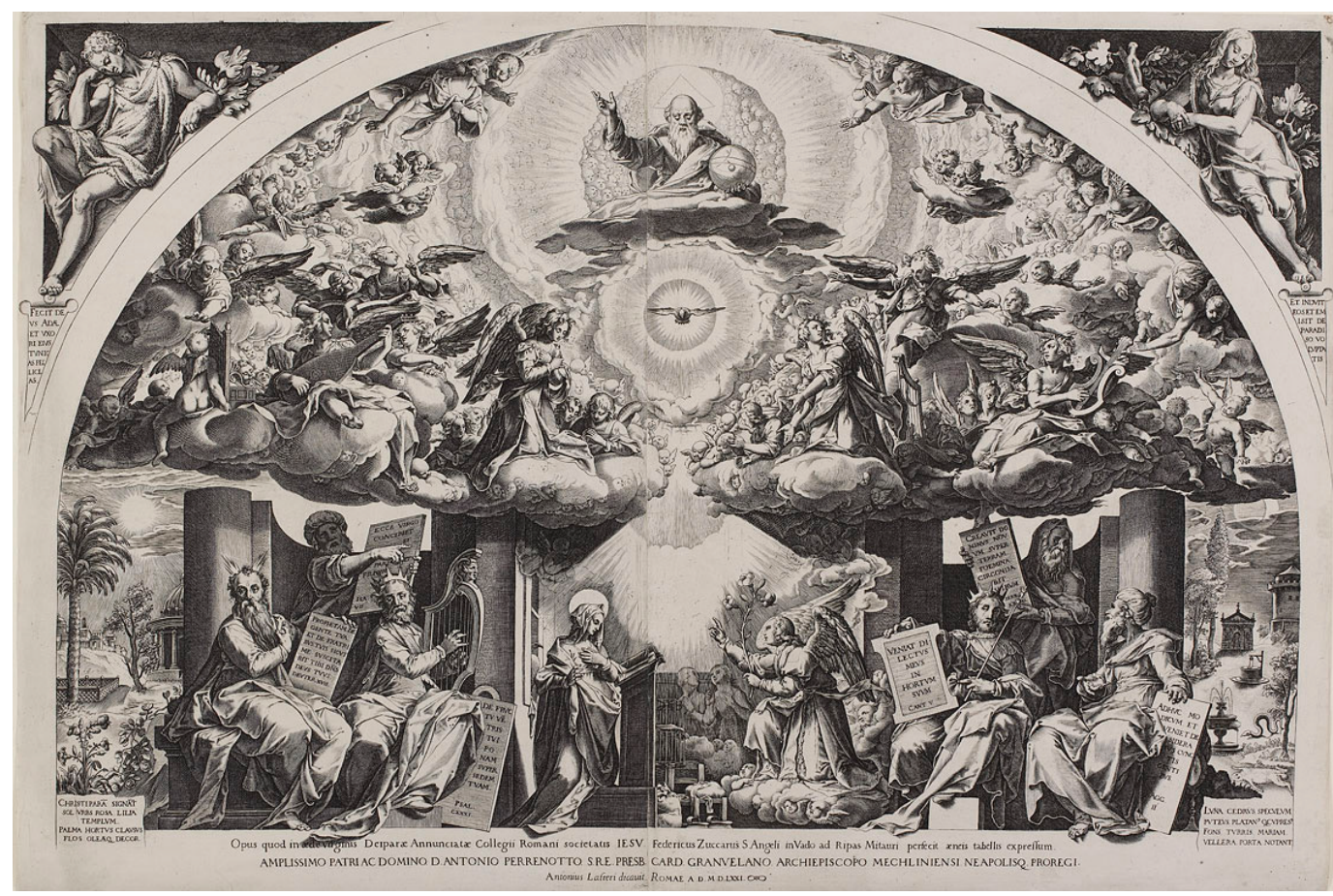

Fig.1. La Anunciación con santos y profetas, Cornelis Cort, 1570

gl'arcangeli, le virtù, i principati, le potestà, le dominationi, $i$ troni, $i$ cherubini, i serafini, i patriarchi, i profeti, gl'apostoli, gl'evangelisti, i martiri, $i$ dottori, i confessori, le vergini e tutti i Beati (....).

Ottaviano Zuccari concedió una gran importancia a la descripción del cielo, tanto en el glosario de términos publicado en el año 1628 como en el manuscrito de su mano, una especie de borrador identificado recientemente en la Biblioteca Apostólica Vaticana, y esta cuestión podría ponerse en relación con el modo en el que su padre elevó una escena evangélica tradicionalmente íntima a una nueva dimensión espiritual en la que entraron a formar parte nuevos personajes cuyo papel en La Anunciación, hasta entonces, solo había sido destacado en los escritos teológicos.

\section{El cardenal Francisco de Toledo y Federico Zuccari}

En este ámbito de estudio, resulta obligado preguntarnos quien o quienes fueron los interlocutores de Federico Zuccari en este periodo de trabajo en la iglesia de Santa Maria dell'Annunziata, y, sobre todo, si alguno de ellos era miembro de la Compañía de Jesús. Una de las hipótesis más sugestivas sería la posibilidad de poner en relación al Cardenal Francisco de Toledo con nuestro artista, a partir de la larga etapa de residencia en Roma del religioso, como profesor de filosofía y teología del famoso Collegio Romano, ${ }^{17}$ el primer centro universitario de la institución, y un reputado predicador en la Corte Pontificia. Por desgracia, la ausencia de un estudio sistemático acerca del jesuita ${ }^{18}$, es decir, de su formación cultural,

${ }^{17}$ El Cardenal Francisco de Toledo, oriundo de Córdoba (1532-1596), escribió cuatro obras dedicadas a la filosofía: De Logica, De Physica, De Generatione y De Anima y varios volúmenes sobre cuestiones teológicas. Véase el perfil bio-bibliográfico del jesuita en la monografía: SANTOS HERNÁNDEZ A., Jesuitas y obispados. La Compañia de Jesús y las dignidades eclesiásticas, Madrid, 1999, p. 124 y ss. El jesuita se instaló en Roma el 24 de Mayo de 1559 y ese mismo año comenzó a enseñar Metafísica en el Collegio Romano. Su estancia en la corte pontificia se dilató hasta su muerte, acaecida en el año1596.

${ }_{18}$ Un resumen de la vida y obras del Cardenal Francisco de Toledo en SOMMERVOGEL C., Bibliotheque d'écrivains de la Compagnie de Jésus, vol. VIII, pp.64-82, Paris, 1893 y O’NEILL C.E. S.I. -DOMÍNGUEZ J. Mª, 
sus aportaciones a la literatura teológica o su papel en el complejo panorama político europeo, impide definir algunos aspectos colaterales, tales como su relación con los artistas o el papel que jugó en el impulso constructivo de la Compañía de Jesús durante el último tercio del siglo XVI. ${ }^{19}$

A día de hoy, por lo tanto, resulta imposible ratificar la posibilidad de un encuentro o de una relación de amistad entre Zuccari y el jesuita aunque si que hemos podido confirmar que algunas de las publicaciones más relevantes del Cardenal se encontraban en las bibliotecas de los artistas y prelados más importantes de esta etapa. Giovanni Battista Paggi, un conocido pintor oriundo de Génova, viejo amigo de Zuccari al que éste conoció durante su exilio en Florencia; el cordobés Pablo de Céspedes, activo en Roma en la misma etapa en la que Federico pintaba el fresco de La Anunciación, y el tratadista y conocido pintor andaluz Francisco Pacheco custodiaron en sus residencias algunos de los textos más importantes del Cardenal Toledo. La ausencia de datos sobre la biblioteca de nuestro artista, cuyo inventario no ha sido localizado todavía, no permite establecer con claridad el método de formación cultural de Federico Zuccari, de ahí que los datos conocidos acerca de los títulos que custodiaban dos de sus amigos más cultos, Paggi y Céspedes, confirman la existencia de afinidades literarias entre la reducida comunidad de artistas letrados de la época. ${ }^{20}$

La identificación de materiales manuscritos recientemente permiten confirmar que el Cardenal Francisco de Toledo se implicó personalmente en el proceso de construcción de la iglesia romana de Il Gesù, el gran proyecto constructivo de la Compañía en sus inicios, y que se encuentra apenas a doscientos metros de la primera parroquia en la que trabajo Federico Zuccari, e incluso, el jesuita conoció de primera mano a los arquitectos y a los artistas convocados en la construcción del primer templo que la Compañía de Jesús erigía en Roma, entre ellos nuestro pintor. A este respecto, un documento identificado en la última década en la Biblioteca Apostólica Vaticana recoge precisamente su propia visión del proceso de edificación de la iglesia y el modo en el que se había gestionado la erección del mismo, señal inequívoca del interés que despertó en el jesuita el proyecto de construcción de Il Gesù. ${ }^{21}$

\section{La intervención de Federico Zuccari en la Iglesia de Il Gesù}

Animae in purgatorio non sunt securae de erarum salute, saltem omnes Leon X, Bula, Exsurge Domine, ("Levántate, Señor") ,1520 22

Federico Zuccari fue invitado a participar en la ornamentación de la capilla Vettori en la iglesia romana de Il Gesù, denominada como Cappella degli Angeli, a principios de la década de 1590. El programa iconográfico elegido por el artista refleja, sin ninguna duda, que había

Diccionario histórico de la Compañía de Jesús, vol. IV, pp.3807-3808, Roma- Madrid, 2001. Para las ediciones críticas a la obra de Aristóteles véase LOHR H., Latin Aristotle Commentaries: Renaissance Authors, Firenze, 1988, pp.458-464

19 Para esta cuestión véase MORALEJO ORTEGA M., "Francisco de Toledo y las artes", en Actas del XIV Congreso Nacional de Historia del Arte, Málaga 18-21 Septiembre del 2002, pp.809-816. Nuevos datos en IDEM., El Cardenal Francisco de Toledo S.J.. Nuevos análisis a la luz de su papel en la corte pontificia, en I Seminario Cientifico, La Italia española (s. XVI-XVII), en prensa.

${ }^{20}$ Véase el inventario de libros de Pablo de Céspedes realizado a su muerte en 1608: RAMÍREZ DE ARELLANO R., «Artistas exhumados: Pablo de Céspedes, pintor, escultor, arquitecto, literato insigne y ¿músico?», en Boletín de la Sociedad Española de Excursiones, n. 11, 1903, pp. 204-236 y n.12, (1904), pp. 34-41. Agradezco al profesor Manuel Pérez Lozano sus comentarios acerca del documento original. Un análisis de la biblioteca de Giovanni Battista Paggi en LUKEHART P.M.,

Contending ideales: The nobility of Giovanni Battista Paggi and the nobility of painting, The John Hopkins University, 1988. El profesor Bassegoda i Hugas ha analizado con detenimiento los títulos y los autores que Francisco Pacheco utilizó para la redacción de El arte de la pintura en la edición moderna del tratado del pintor citada en la nota 12.

21 Véase MORALEJO ORTEGA M., «Una nota manuscrita de Francisco de Toledo S.I. sobre la construcción de la iglesia de Il Gesù », en Archivo Español de Arte, Tercer Trimestre 2003, pp.74-81

22 Véase la nota siguiente. 
asimilado la preceptiva teológica jesuítica, una dependencia conceptual que solo puede explicarse a la luz del paulatino adoctrinamiento catequético que, posiblemente, recibió de un miembro de la Compañía, el mismo que le proporcionó las directrices generales para afrontar el conjunto decorativo. Así, el conjunto responde a un modélico esquema iconográfico que repite la tripartición descrita arriba a través de un complejo universo figurativo en el que confluye la noción de la Iglesia Terrena, Triunfante y Militante.

La espectacular recreación pictórica realizada para la composición de las escenas más ambiciosas, en cuanto a la temática, sorprende aún más si pensamos que Federico Zuccari realizó un proyecto muy original y totalmente independiente de los realizados anteriormente, al igual que sucedió en La Anunciación con santos y profetas, aun cuando tuvo muy presente la concepción estética que había vehiculado la representación del infierno y el purgatorio en la cúpula de Santa Maria dei Fiori en Florencia, concluida en 1579. A este respecto, y más allá de la atención que el pintor prestó a ciertos episodios del Antiguo Testamento, las escenas más sugestivas desde el punto de vista iconográfico en la capilla jesuítica son aquellas que describen el Paraíso, el Purgatorio y el Infierno. Federico Zuccari estaba muy familiarizado con la problemática que encerraba cada uno de estos lugares, puesto que también había realizado una serie de dibujos que debían ilustrar la obra de Dante Alighieri, la Divina Comedia, durante su etapa de residencia en la corte escurialense de Felipe II. ${ }^{23}$

No se trataría, y en este aspecto deseamos incidir, de la única fuente utilizada, dado que en un espacio promovido por la Compañía las variantes en la interpretación acerca del asunto estuvieron también muy presentes. Así, no podemos olvidar que San Roberto Bellarmino mostró su desacuerdo con la interpretación - a su juicio de inspiración luterana- que François Perrot había dado acerca del famoso texto de Dante, y alentó el nacimiento de una corriente de opinión que se debatía entre la contemplación de un Dante devoto, en clara oposición con el Dante crítico. ${ }^{24}$

La historiografía del arte, que se ha ocupado del tema en las últimas décadas, ha reflexionado en torno a esta cuestión, es decir la originalidad de la propuesta de Federico Zuccari en la representación del purgatorio, pero no ha incidido en las corrientes de opinión que vehicularon - desde la óptica jesuítica- tal representación. ${ }^{25}$ Federico Zeri, a este respecto,

23 Véase la nota siguiente.

${ }^{24} \mathrm{La}$ angeología escolástica, sobre todo la tomista, influyó en las representaciones del Purgatorio y el Paraíso descritas en La Divina Comedia. En el purgatorio se subrayó el servicio de los ángeles a los hombres en el camino de la purificación hacia la contemplación divina. En el paraíso, en cambio, se describió a los ángeles como vida en la luz y en la santidad a los ojos de Dios. Federico Zuccari realizó sus dibujos inspirándose probablemente en la producción sobre la obra de Dante ideada durante su estancia en el Monasterio-Palacio de San Lorenzo de El Escorial. No se conoce el destinatario de este conjunto, conservado por Ottaviano Zuccari, y que después pasó a formar parte del fondo de dibujos de la Galeria de los Uffizzi con la colocación GDSU 3474 F-3561 F. A este respecto, MICHAEL BRUNNER ha manifestado: Possiamo supporre che lo Zuccari svilupasse la sua passione per la Divina Comedia negli anni settanta durante i lavori per la cupola (frescos del Duomo de Florencia) poichè a mio parere nessuna delle sue opere sinora conservate e databili prima del suo secondo soggiorno fiorentino porta qualsiasi riferimento all'opera dantesca, mentre in alcune sue opere posteriori si evidenzia la conoscenza del divino poema. È ad esempio il caso degli affreschi delle volte della Cappella Paolina in Vaticano e della cappella degli Angeli della chiesa del Gesù a Roma. Cfr., BRUNNER M., «Imprese tardocinquecentesche di illustrazione dantesca: circostanze e motivazioni», in Federico Zuccari: Le idee, gli scritti, ed. Electa, 1997, pp. 159-170 y del mismo autor «Storia del' Dante historiato da Federico Zuccaro», in Federico Zuccari e Dante, catálogo de la exposición de Torre de’ Passeri, 1993, Milano, pp. 71-74

25 El texto en francés fue publicado con el título L'art religieux aprè le Concile de Trent, Paris, 1932. Para la traducción al castellano del texto de E. MÂLE, El arte religioso de la Contrarreforma, Madrid, Editorial Encuentro, 2001. El especialista francés señaló que la Virgen asumía el papel de consoladora de las almas purgantes en la literatura de la época, citando ejemplos significativos como el de Juan de Cartagena, quien refería cómo la Inmaculada bajaba al Purgatorio para salvar a las almas el día de Navidad, o Gelsomini que citaba también el día de la Asunción. Santa Brígida de Suecia sostenía que la Virgen vigilaba como una madre el proceso de purificación de las almas tratando de amortiguar su sufrimiento. Véase a este propósito BALASS G., «Five hierarchies of intercessors for salvation: The decoration of the angels'chapel in the Gesù », in Artibus et Historiae, 2003, pp. 177-208. La autora no alude en este artículo a la composición figurativa sobre el Purgatorio realizada por Federico Zuccari en el Convento del Corpus Christi de Valencia. 


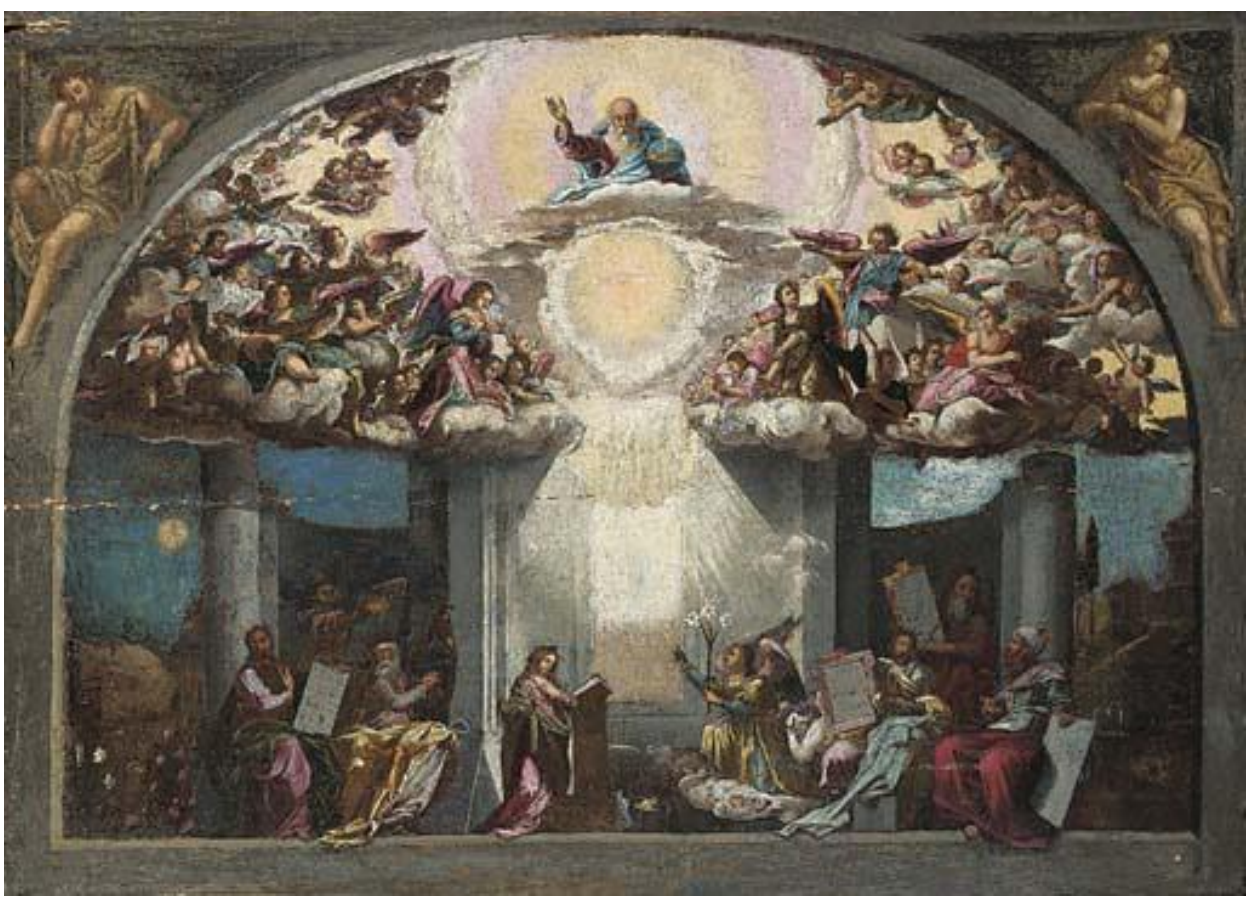

Fg.2. La Anunciación con santos y profetas, seguidor de Federico Zuccari, finales del siglo XVI, mercado del

aludió a la rápida asimilación del artista de los modelos iconográficos más novedosos, ideados tanto en el área florentina como en la zona de Cremona, pero no se detuvo a analizar el modo en que ciertas lecturas teológicas canalizaron la actuación del pintor. ${ }^{26}$

Así mismo, conviene recordar que la decoración ideada por Federico Zuccari para la escena del purgatorio buscaba la promoción de la iconografía angélica - sobre todo aquella vinculada con el Ángel Custodio- tema en el que también Bellarmino había incidido en sus Disputationes, dado que, a su juicio, los custodios eran los coprotagonistas del lugar. En este sentido, Federico Zuccari concedió también una gran importancia a las figuras angelicales, que dispuso incluso en mayor número respecto a las almas del Purgatorio, y que adoptaron un papel muy relevante en la composición como intercesores antes Dios y la Virgen por la salvación de las almas.

El culto angélico había sido promovido con carácter de continuidad, gracias a la activa intervención del fundador de la Compañía durante las reformas de las antiguas Termas de Diocleciano y su apertura al culto católico, así como en la posterior fundación de la iglesia romana de Santa Maria degli Angeli. Personajes muy cercanos a Federico Zuccari, como el Cardenal Federico Borromeo o San Felipe Neri, también promovieron en sus áreas de actuación la devoción a los ángeles y el clima religioso era muy proclive a la escritura de libros sobre el tema, tal y como manifestaron algunos especialistas residentes en Roma en la época, como San Luís Gonzaga, Giovanni Maria Tarsia o Antonio del Duca.

26 ZERI F., Pittura e Controriforma: L'arte senza tempo di Scipione da Gaeta, ed. Neri Pozza, Roma, pp.37, 2001 $\left(1^{a}\right.$ ed. Giulio Einaudi, Torino, 1957): [...] « Federico Zuccari accanto alla attività di Corte svolge una attenta opera di combinatore e facitore di immagini divozionali, che soddisfino alle nuove esigenze pietistiche. (...) Negli affreschi della Cappella degli Angeli al Gesù, il meditato rigore cromatico e compositivo fa toccare ai principi del Titi una realizzazione di compiutezza insuperabile, grazie anche alla grande cultura dello Zuccari, che, per la bisogna dell' "Arte Sacra", rivede e annota una smisurata quantità di produzioni pittoriche delle più varie e delle più disparate regioni, dalla Firenze del tardo Quattrocento alla Cremona di Vincenzo e Antonio Campi » [...]. 
Federico Zuccari y la Compañía de Jesús

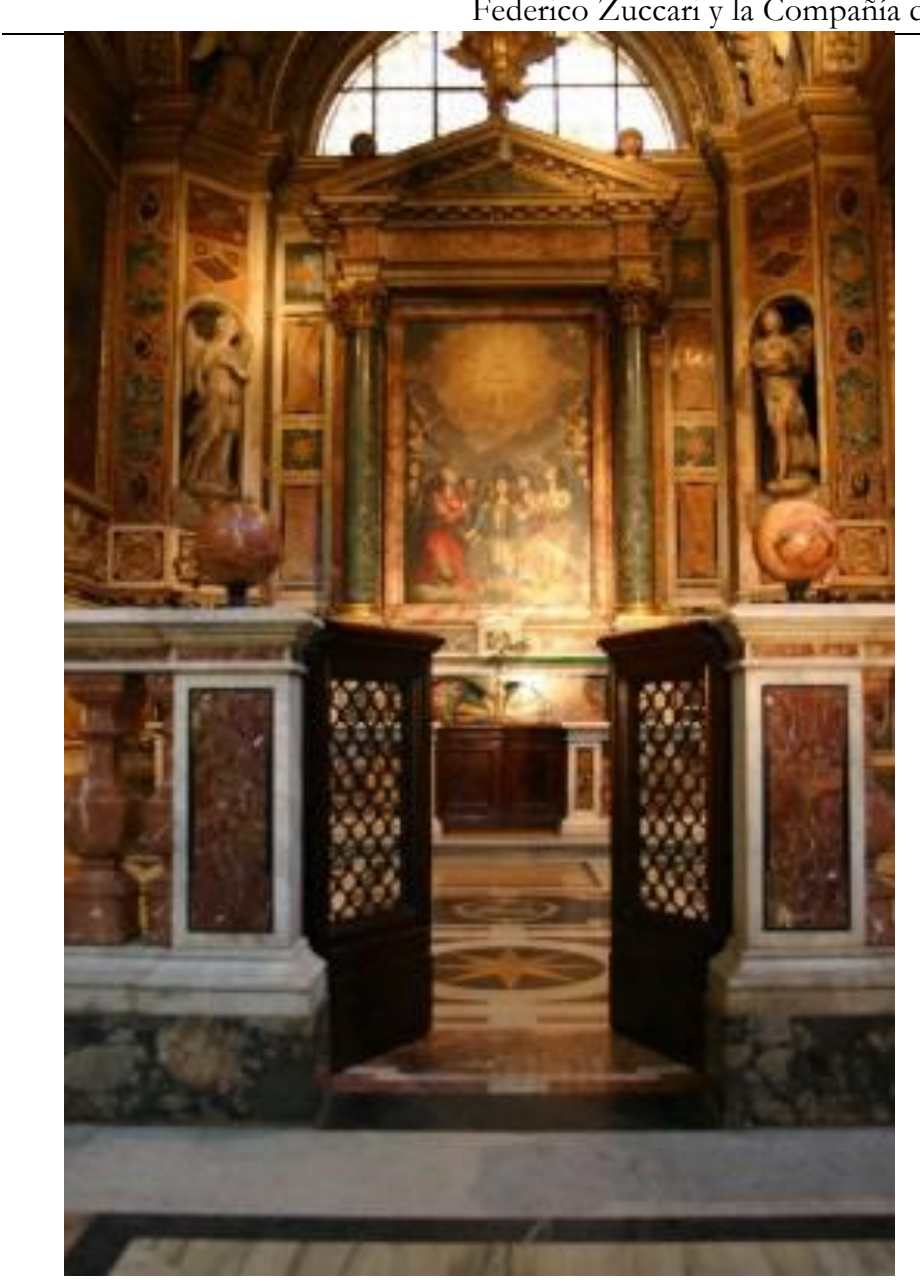

Fg.3. Detalle de la escena "El Purgatorio", Federico Zuccari, 15931596,Capilla de los Ángeles, Iglesia de Il Gesù, Roma

Federico Borromeo, uno de los mejores interlocutores de Federico Zuccari, expresó su opinión al respecto en su tratado De Pictura Sacra, y señaló qué direc-trices iconográficas debían seguir los pintores para la representación de los ángeles. Así, y en aras de su exaltación, sugirió que éstos llevasen siempre alas, para subrayar su movilidad, y se representasen desnudos para que resultara más sencillo comprender que eran inmunes al contagio de las miserias humanas, directrices estilísticas que fueron respetadas por la inmensa mayoría de pintores. $^{27}$

Una de las prioridades de los teólogos era establecer nuevas bases teóricas para el desarrollo de una argumentación a favor de la representación de los ángeles, un asunto que también concitó el interés de Federico Zuccari en sus aportaciones a la Teoría del Arte. A este respecto, existen claras similitudes entre el modo de actuación secundado por el pintor en Il Gesù y las aportaciones textuales, dado que compartían un objetivo común: convertir a los seres alados en instrumentos figurativos de la propaganda fideista.

27 Véase BORROMEO F., Musaeum, Milano, 1625 así como la reciente edición crítica de este tratado en inglés: JONES P.M., Sacred painting. Musaeum, Cambridge, Massachusets, Harvard University Press, 2010 y de la misma autora Federico Borromeo e l'Ambrosiana: Arte e reforma católica nel XVII secolo a Milano, ed. Vita e Pensiero 1997 (ed. en inglés, Cambridge University Press, 1993). Así mismo véase también AGOSTI B., Della pictura sacra libri due, Pisa, Scuola Normale Superiore di Pisa, 1994; MARGHETICH T., «Per una rilettura critica del Musaeum di Federico Borromeo », en Arte Lombarda, no 84/85, 1988, 1/2, pp. 102-118; COPPA S., " Federico Borromeo teorico d'arte: annotazioni in margine al "De pictura Sacra" ed al "Musaeum ", en Arte lombarda, 15, 1970, vol. I, pp. 65-70; y la monografía QUINT A., Cardinal Federico Borromeo as a patron and a critic of the arts and his Musaeum of 1625, New York, Garland, 1986 
Además el artista no pudo sustraerse al éxito alcanzado por el misal romano de Pio V, editado en 1570, que incluso invitaba a los sacerdotes a celebrar las misas en honor de los ángeles el día de su festividad, y posiblemente actuó en consecuencia concediendo a estas figuras un rol preponderante en la representación de El Purgatorio. Federico Zuccari fue un paso más allá en la redacción de su tratado, L'idea de' pittori, scultori ed architetti, que, como hemos demostrado en otra sede, comenzó a escribir en la década de 1590 coincidiendo con el encargo de la Compañía en Roma, otorgando autoridad al principio del disegno divino, que se manifestaba a través de la idea y de las acciones de los ángeles. La articulación de este sistema le permitió establecer la existencia de dos categorías: el disegno angelico interno, aquel que debe vincularse con su concepción mental, y el disegno angelico esterno, el que está relacionado con la plasmación figurativa.

Las directrices teológicas suministradas por la Compañía al pintor reforzaron también la adopción de un programa decorativo inspirado en un principio de comparación, es decir, se establecía que el principe, Dios, estaba al mando de una multitud de ángeles, hombres y otras criaturas que conformaban un numeroso grupo a su servicio. Esta multitud estaba llamada a configurar un mundo celeste y terrenal, que gozaba de idéntica estructura gubernamental, una concepción mental que tuvo como eco la propia elaboración iconográfica de Federico Zuccari en Il Gesù.

Sin embargo, todavía a día de hoy, desconocemos cómo y quienes fueron los confidentes del artista en la configuración de su ideario estético y qué tipo de conceptos le transmitieron en cada circunstancia específica. Así, y para ahondar en el tema que nos ocupa acerca de la presencia angélica en la representación del purgatorio, debemos también señalar otros nombres pertenecientes al círculo más íntimo del pintor cuyas aportaciones deben resaltarse. A este propósito, conviene señalar las coincidencias y similitudes formales entre la línea de pensamiento de Gaspare Murtola, secretario del Duque de Saboya, y Federico Zuccari. El primero, que ejerció un importante papel en la corte de Turín, asesoró y aconsejó al pintor en los encargos que éste recibió del noble en el último tramo de su vida, e incluso, tal y como proponemos aquí, pudieron intercambiar datos acerca de las conexiones entre el disegno angelico, la pintura y la poesía.

El inicio de la relación entre ambos debe fecharse en el último cuarto del siglo XVI en el marco de las reuniones celebradas en la Accademia degli Insensati, una institución con un marcado acento cultural de la que ambos formaban parte junto con otros distinguidos miembros de la sociedad italiana, casi todos oriundos de Perugia. Gaspare Murtola elogió en dos composiciones poéticas la trayectoria pictórica de Federico Zuccari, aunque una de las obras, hasta hoy, no se había vinculado con la experiencia figurativa del pintor porque solo aparece en las antologías poéticas publicadas por Gaspare Murtola. Este poema reviste gran interés porque describe las características iconográficas de una pintura, ideada por el vadese, en el que la Virgen está rodeada por un coro de ángeles. Murtola aludía a los contrastes lumínicos y cromáticos de la escena representada, además de a otras cuestiones, pero aquello que conviene subrayar es la noción de sapienza que, a juicio del poeta, había sido transmitida al pintor por los propios ángeles.

Mayores conexiones temáticas presenta con la teología de la época la contribución de Gaspare Murtola, publicada en el año 1608. Nos referimos al largo poema de La creatione del mondo, una extensa reflexión acerca de la creación de los ángeles, las guerras internas, la jerarquía interna del cuerpo angélico o su triunfo en la esfera celestial. ${ }^{28}$ Las estampas que ilustran el libro de Murtola, todavía pendientes de un estudio puesto que no se ha identificado al ideólogo de las mismas, recrean escenas como "la creación del mundo", "la caída de los ángeles", "la lucha con los demonios", y presentan evidentes vinculaciones simbólicas y figurativas con la escena del purgatorio pintada por Zuccari en Roma.

${ }^{28}$ Hemos revisado una copia de la edición original: MURTOLA G., Della creatione del mondo, poema sacro, Venecia, 1608. Otros datos sobre el escritor y su contribución literaria en el volumen: Politica e cultura nell'età di Carlo Emanuele I: Torino, Parigi, Madrid, ed. Leo S. Olschki, Firenze, 1999. 
Junto al poder evocador de la contribución de Murtola, tampoco se ha subrayado la influencia en la representación del Purgatorio de Federico Zuccari de un texto contemporáneo publicado por el franciscano Giovanni Luigi Barbieri en 1593. Esta obra alcanzó un gran éxito hasta principios del siglo XVII, con la impresión de sucesivas ediciones, quizá porque fue escrita en italiano con el título 'Della morte et dell'anime separate", y en la que un sencillo diálogo entre padre e hija servía como pretexto para describir episodios teológicos de gran complejidad. Este aspecto, es decir, la presencia de una figura femenina, nos induce a pensar que el público al que se dirigía el franciscano era mayoritariamente de este sexo, pero no solo, dado que la utilización de este género debe vincularse con la literatura de los exempla. Así, el religioso introdujo en el texto todo tipo de cuestiones adoptando planteamientos ideológicos muy simples, para afrontar, en cambio, temas muy complejos, como la separación de las almas y los contactos entre el mundo de los vivos y el purgatorio. El lenguaje utilizado, mucho más sencillo que la compleja redacción de Roberto Bellarmino y sus seguidores en lengua latina, y las respuestas del franciscano confirman que existía la necesidad de reforzar las creencias en torno a la recíproca ayuda entre los vivos y los muertos. Además, el autor afianzó la noción sobre la validez de los sufragios por el alma de los difuntos como el método de salvación de los vivos y el soporte de los purgantes, silenciando, en cambio, cualquier comentario acerca de las indulgencias que tantos comentarios despectivos habían suscitado entre los luteranos. La pacífica convivencia entre "los vivos" y "los muertos" aparece reflejada con nitidez en este texto, una idea que también fue retomada por Federico Zuccari en su recreación del purgatorio en la iglesia romana de Il Gesù.

La iniciativa de Barbieri no fue un hecho aislado, de hecho, podemos adscribir al mismo ámbito una publicación sobre el tema, también en lengua vulgar, escrita por el mínimo Padre Tomás Vandini, y editada en Bolonia apenas unos años más tarde con el título "Trattato del purgatorio". A nuestro juicio, se podrían incluso establecer una continuidad entre la obra del francisco y la del mínimo, dado que ambos publicaron sus textos en la misma editorial y apostaron por un hilo argumental análogo para justificar la existencia del purgatorio señalando incluso:

$$
\begin{aligned}
& \text { "[...] sono pieni di speranza i purganti perche sono certi, e sicuri della divina visione, e della gloria } \\
& \text { eterna, cosa che non puo apportare, se non allegrezza grande }[\ldots] \text { ". }
\end{aligned}
$$

El tema del purgatorio constituía, por lo tanto, un importante reclamo y confirma que el modus pictoricus utilizado por Federico Zuccari en Il Gesù reflejó la asimilación, por parte del artista, de los postulados teológicos de su época, pero también una dependencia conceptual que solo puede explicarse a la luz de un paulatino adoctrinamiento catequético por parte de un miembro de la Orden que le proporcionó las directrices para afrontar la decoración mural de la capilla.

Las dudas en torno a cómo afrontar el programa decorativo podían también resolverse a través de la utilización de otros vehículos de comunicación más gráficos, como las imágenes ideadas por el jesuita mallorquín Jerónimo Nadal en sus Evangelicae Historiae Imagines. ${ }^{29}$ La popularidad alcanzada por estas imágenes, y la trascendencia de las representaciones figurativas análogas, como las creadas por Federico Zuccari para la iglesia de Il Gesù, tuvo su eco en un lienzo encargado por el Patriarca San Juan de Ribera al propio pintor italiano. Esta petición debe vincularse con la política de mecenazgo del Patriarca en Valencia y con las adquisiciones que el prelado realizó para la decoración de la Capilla del Sufragio de las Almas en el convento del Corpus Christi. A este respecto existe una explicita semejanza compositiva

${ }^{29}$ Las ilustraciones de Jerónimo Nadal, publicadas en Amberes en 1593, posiblemente influyeron en las representaciones ideadas por Federico Zuccari para la Compañía de Jesús en varias circunstancias. A este respecto véase el articulo de SALVIUCCI INSOLERA L., "Le illustrazioni per gli esercizi spirituali intorno al 1600», in Archivium Historicum Societatis Iesu, 1991, v. 60, n.119, pp. 161-217 y de la misma autora una contribución más reciente, «L'uso di immagini come strumento didattico-catechetico nella Compagnia di Gesù», en VV.AA., I gesuiti e la ratio studiorum, ed. Bulzoni, Roma, 2004, pp.191 y ss. 


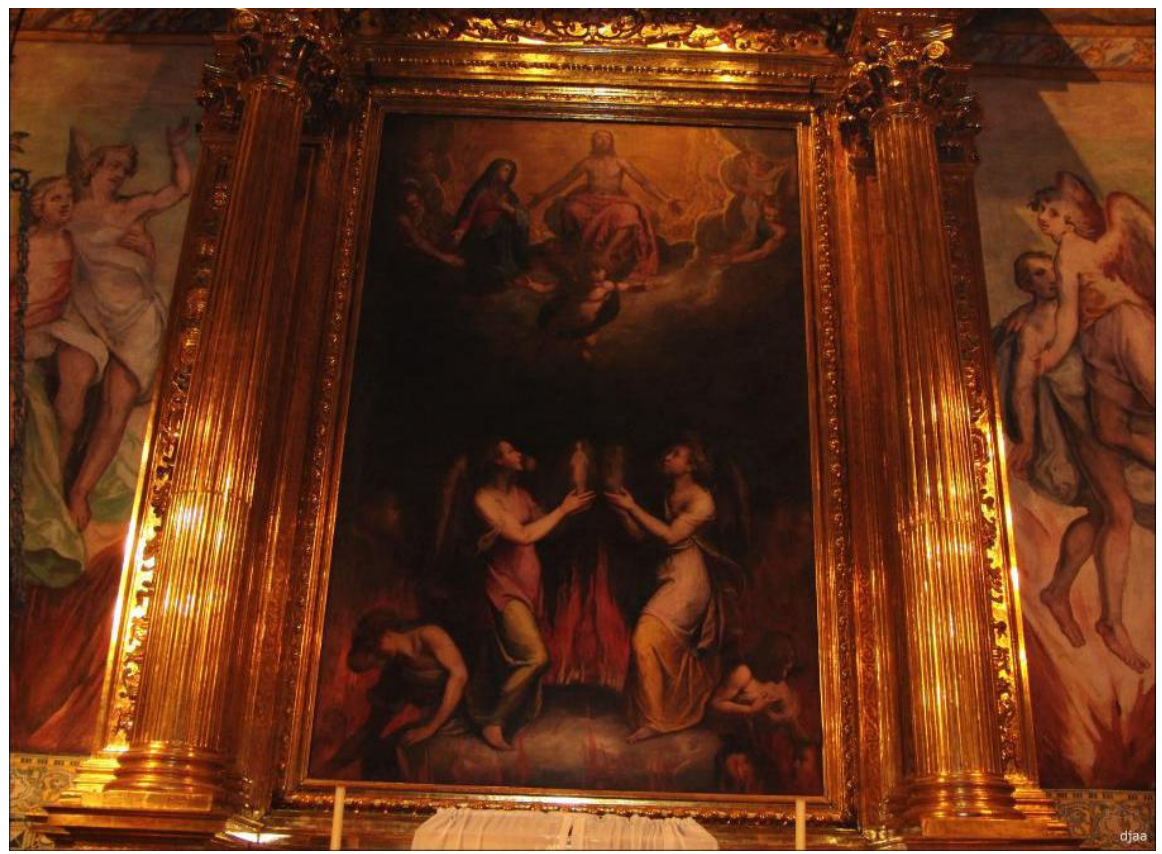

Fg.3. El Purgatorio, Federico Zuccari, principios del siglo XVII, Capilla del Seminario del Corpus Christi, Valencia

entre la escena del Purgatorio recreada en la Capilla Vettori y la elegida para el templo valenciano, ideadas por Federico Zuccari a partir de una concepción visual muy diferente.

El encargo valenciano, en este sentido, constituye la única contribución del italiano a la temática del Ars Morendi que tanto éxito alcanzó en el área valenciana desde mediados del siglo $\mathrm{XV}{ }^{30}$ tema sobre el que ha eludido pronunciarse la historiografía italiana, fundamentalmente porque solo han mencionado en sus estudios el legado escurialense del artista. ${ }^{31}$ Conviene, así mismo, diferenciar ambos encargos, en cuanto a la materia de ejecución y el formato elegido para la representación. De esta forma, se observa que en Roma se privilegió la utilización del fresco sobre muro, ${ }^{32}$ para adaptarse a las dimensiones horizontales de la pared, mientras que en Valencia se usó el lienzo como soporte y el formato vertical con el fin de adecuarse a las difíciles condiciones de expedición desde Roma. El lienzo valenciano fue pintado jugando con los elementos estilísticos e iconográficos ya

${ }^{30}$ Fernando Benito Domenech cita otras versiones del tema del Purgatorio en las provincias de Castellón y Valencia, probablemente ejecutadas por autores locales a la luz de la composición de Zuccari, cuya iconografía se popularizó gracias a las predicaciones a favor de una política del sufragio en la zona y el proceso de recuperación de una temática rechazada por las corrientes heréticas. Igualmente aludió a la difusión de los grabados de Cornelis Cort en área hispánica con la representación de La Disputa del Sacramento, en donde se repiten las mismas representaciones de la Virgen y Cristo junto a las versiones de Philippe de Galle y Maarten van Heemsckerk. Cfr., BENITO DOMENECH F., Pintura y pintores en el Real Colegio de Corpus Christi, Valencia, $1980, n^{\circ} 294$, pp. 336-337 (véase la obra para la reproducción fotográfica del lienzo valenciano de Federico Zuccari) y NAVARRETE PRIETO B., op.cit., 1998, pp. 129, 229 y 272.

31 Cfr., ACIDINI LUCHINAT C., op.cit., 1997, vol. II, p. 436. Esta contribución solo recoge la intervención de Federico

Zuccari en la decoración de la capilla de los ángeles de Roma pero no alude al lienzo conservado en Valencia con la temática del Purgatorio. Igualmente ALESSANDRO ZUCCARI omite cualquier noticia relativa a la obra valenciana en los artículos dedicados al tema, la misma pauta de actuación de HIBBARD H., «Ut picturae sermones": the first painted decorations of the Gesù » en WITTKOWER R. - JAFFE I.B., Baroque Art: The Jesuit Contribution, New York, 1972, pp. 29-49.

${ }^{32}$ No se han identificado todavía, si es que fueron realizados, los dibujos preparatorios que Federico Zuccari ideó para la capilla de la iglesia de Il Gesù. 
utilizados en el fresco romano, representándose en la parte inferior las almas del Purgatorio auxiliadas por algunos ángeles, escena que se cierra con la disposición simétrica de dos querubines en el centro de ambas composiciones, que presentan a Cristo y a la Virgen en la Gloria junto a dos almas purificadas. ${ }^{33}$ La representación de un putto o un ángel en la pintura hispánica, que desciende hacia el purgatorio desde la Gloria con una serpiente enrollada en torno al cuerpo, introduce un ulterior elemento de análisis.

Se desconocen las circunstancias que mediaron en el encargo del lienzo a Federico Zuccari por parte, presumiblemente, de Miguel de Espinosa, obispo auxiliar de Valencia y hombre de confianza del Patriarca San Juan de Ribera en la Roma del último cuarto del siglo XVI. ${ }^{34}$ El hallazgo de una breve anotación en un manuscrito del archivo del Corpus Christi, titulado Noticias del Colegio señalaba literalmente: El cuadro de las almas ${ }^{35}$ fue pintado en Roma por Federico Zuccari y costó 250 escudos; dato que desestimaba anteriores atribuciones a Bartolomeo Carducho, discípulo del propio Zuccari, o a Francisco de Ribalta. Esta noticia de archivo, la única que vincula el cuadro valenciano a Federico Zuccari, confirma el alcance de una iconografía de carácter autónomo e innovador a ambos lados del mediterráneo. Se desconocen las razones específicas que llevaron al Patriarca a solicitar una pintura con esta temática. En este sentido, el inventario de la rica biblioteca del Patriarca San Juan de Ribera, publicado por el profesor Cárcel Ortí, ${ }^{36}$ puso ya de manifiesto el especial interés del fundador del Corpus Christi por las disciplinas humanísticas, en especial, cuestiones teológicas con la presencia de varias ediciones de las publicaciones del Cardenal Toledo y otros jesuitas italianos con publicaciones vinculadas a cuestiones más iconográficas como Antonio Possevino. A las noticias extraídas de la biblioteca del San Juan de Ribera ${ }^{37}$ se une la parcial recopilación de los sermones manuscritos del Patriarca, que sugieren su especial vinculación con la política religiosa de los sufragios y la adoración eucarística, temas ya señalados por su parentesco con el purgatorio. En cuanto a las fuentes teológicoartísticas utilizadas en la realización de estas representaciones del tercer lugar, es necesario diferenciar el sentido último dado a ambos proyectos pictóricos. En la iglesia de Il Gesù la decoración se supedita a una promoción de la temática angélica - sobre todo aquella que se refería al ángel custodio, mientras que en el Corpus Christi debía vincularse a la política eclesiástica de promoción de sufragios por las almas difuntas. ${ }^{38}$

${ }^{33}$ El papel de la Virgen como intermediaria y mediadora en el Purgatorio entre las almas penitentes y Cristo ha sido descrito por SCARAMELLA P., Le Madonne del Purgatorio. Iconografia e religione in Campania tra Rinascimento e Controriforma, Genova, 199

34 La búsqueda de datos sobre Miguel de Espinosa en los archivos romanos ha resultado infructuosa. Recordemos que este personaje fue el hombre de confianza del Patriarca Juan de Ribera en Roma, tras la renuncia del prelado a emprender un viaje a Italia.

35 BENITO DOMENECH F., op.cit., pp. 336-337 y del mismo autor el catálogo de la institución, Museo del Patriarca, Valencia, ed. Ibercaja, 2000. La obra fue expuesta en la exposición celebrada en Valencia en 1999 con el título La luz de las imágenes. Cfr., GARCÍA MAIQUES R., La luz de las imágenes, Valencia, 1999 (3 vols), vol. II, n.185, pp. 38-39. Benito

Domenech reproduce los datos de la atribución manuscrita a Federico Zuccari ya citados por PONZ A., Viaje de España,

Madrid 1772-1794, 18 vols (ed. facs, Madrid, 1947), vol. III, car X, n 11, p.242

36 Véase CÁRCEL ORTÍ V., "Inventario de las bibliotecas de San Juan de Ribera en 1611», en Analecta Sacra Tarraconensia, vol. XXXIX, 1968, pp.319-379. La biblioteca tenía, al menos, tres publicaciones explícitamente vinculadas con el tema del Purgatorio.

${ }^{37}$ ROBRES LUCH R., Sermones, Vol. I-II, ed. Corpus Christi, Valencia, 1987. Los sermones se publicaron tras una selección previa de aquellos pronunciados entre 1566 y 1591, mientras que el fallecimiento del Patriarca se produjo en 1611

38 Véase HIBBARD H., op.cit., 1972, pp.33. La especialista sostiene que los jesuitas mantuvieron un cierto control en el programa ornamental e iconográfico proyectado para la iglesia de Il Gesù hacia 1580, posiblemente diseñado por San Francisco de Borja, y llevado a la práctica a pesar de la venta de las capillas laterales a privados. Las capillas de la iglesia fueron decoradas jugando con una dualidad temática que permitía el perfecto acoplamiento de los temas de las capillas situadas a la izquierda con las restantes del otro lado. 
Las representaciones figurativas creadas por Federico Zuccari para Roma y Valencia deben ponerse en relación con la publicación, ya señalada en este artículo, de las Disputationes de San Roberto Bellarmino, obra en la que adquieren un peso específico los ángeles como coprotagonistas del evento del purgatorio. El maestro italiano recrea así una escena en la que los ángeles -dispuestos en mayor número respecto a las almas del Purgatorio- son las figuras más relevantes de la composición como intercesores ante Dios y la Virgen por la salvación de las animas.

\section{Los últimos encargos de los jesuitas a Federico Zuccari y la entrada de su hijo Orazio Zuccari en el noviciado de San Andrea a Montecavallo}

[A Bologna] per modo di ricreatione e gustare un poco questa Città che havevo altre volte passato di corso, volsi fermarmi sei, o ottto giorni con questi buoni Padri del Giesu di Santa Lucia (...) i quali mi fecero tante amorevolezze, e cortesie, che io mi tratteni più di quello che mi credeva parte (...) e per non stare del tutto otioso cercai riconoscere questa loro amorevolezza, con (...) un quadro assai grande, nel quale io figurai il Beato Ignazio quando bebbe quella visione vicino a Roma (...). Zuccari F., Passata di Bologna e Ferrara, Bologna, 1609.

Las últimas contribuciones de Federico Zuccari a la ornamentación de las iglesias erigidas por la Compañía de Jesús fueron realizadas en sus años de madurez como artista. Así, el cansancio y la falta de estímulos creativos a partir del año 1600, suscitaron en el pintor el deseo de emprender un largo viaje por las cortes italianas del norte en donde deseaba, por una parte, recuperar el brillo como artista polifacético de antaño, y por otra, despedirse de las amistades que, desde su juventud, había cultivado en esta zona.

Su vida personal en esta etapa también estuvo muy ligada a la Compañía, e incluso los lazos se estrecharon desde principios del siglo XVII gracias a la entrada en el noviciado de Taddeo Zuccari, uno de sus hijos varones, en la Compañía de Jesús, dato que hasta ahora no se había manejado en los estudios previos sobre el artista. ${ }^{39}$ El progenitor no asistió, por encontrarse ausente de Roma, a la ceremonia de los primeros votos de su hijo el 18 de Octubre de 1606, una fecha especialmente significativa porque se conmemoraba la onomástica de San Lucas, el patrón de los pintores. La decisión de entrar en el noviciado de Sant'Andrea a Montecavallo, como un paso previo a la ordenación, pudo deberse también a las presiones ejercidas por el artista, que deseaba garantizar a su hijo una vida serena, dedicada al estudio y a la predicación. Federico Zuccari quizá escondía un secreto más intimo: su intención de ampliar su red de contactos e influencias a través de la Compañía de Jesús, un objetivo que le permitiría obtener un mayor número de encargos que beneficiasen favorablemente su delicada situación financiera, muy maltrecha desde que tomase la decisión de construir el costoso palacete de la Via Gregoriana de Roma.

El pintor, un excelente observador de la realidad de su tiempo, no estaba dispuesto a desaprovechar las oportunidades de ascenso en la pirámide social que le habían proporcionado - y aún podían depararle- sus contactos con la nobleza y las altas jerarquías eclesiásticas. Los cambios en el status social pasaban, inequívocamente, por buscar un futuro digno para sus hijos varones, aquellos que debían salvaguardar el apellido familiar, y para ello, obligó a su primogénito, Ottaviano, a matricularse en la carrera de Leyes, y al término de sus estudios solicitó una carta de recomendación al Duque de Urbino para que le ayudase a posicionarse como jurista. Alessandro Taddeo, otro de sus vástagos, fue apadrinado por el Cardenal Alessandro Farnese, aunque la temprana muerte de este retoño le impidió trazar

${ }^{39}$ Federico Zuccari contrajo matrimonio con Francesca Genga en el mes de mayo de 1578, unión de la que nacieron varios hijos, aunque solo Ottaviano, Isabella, Gerolamo y Orazio alcanzaron la edad adulta. Orazio, el hijo que entró como novicio en la Compañía, nació en Roma el 1 de agosto de 1585 y fue bautizado en la parroquia de San Lorenzo in Lucina. Su ingreso en el noviciado de San Andrés, el centro de formación de los jesuitas en Roma, se produjo el 18 de Octubre de 1605. Véase para esta noticia manuscrita, ARSI, ROMA, vol. 79 , fol. $225 \mathrm{r}$ 


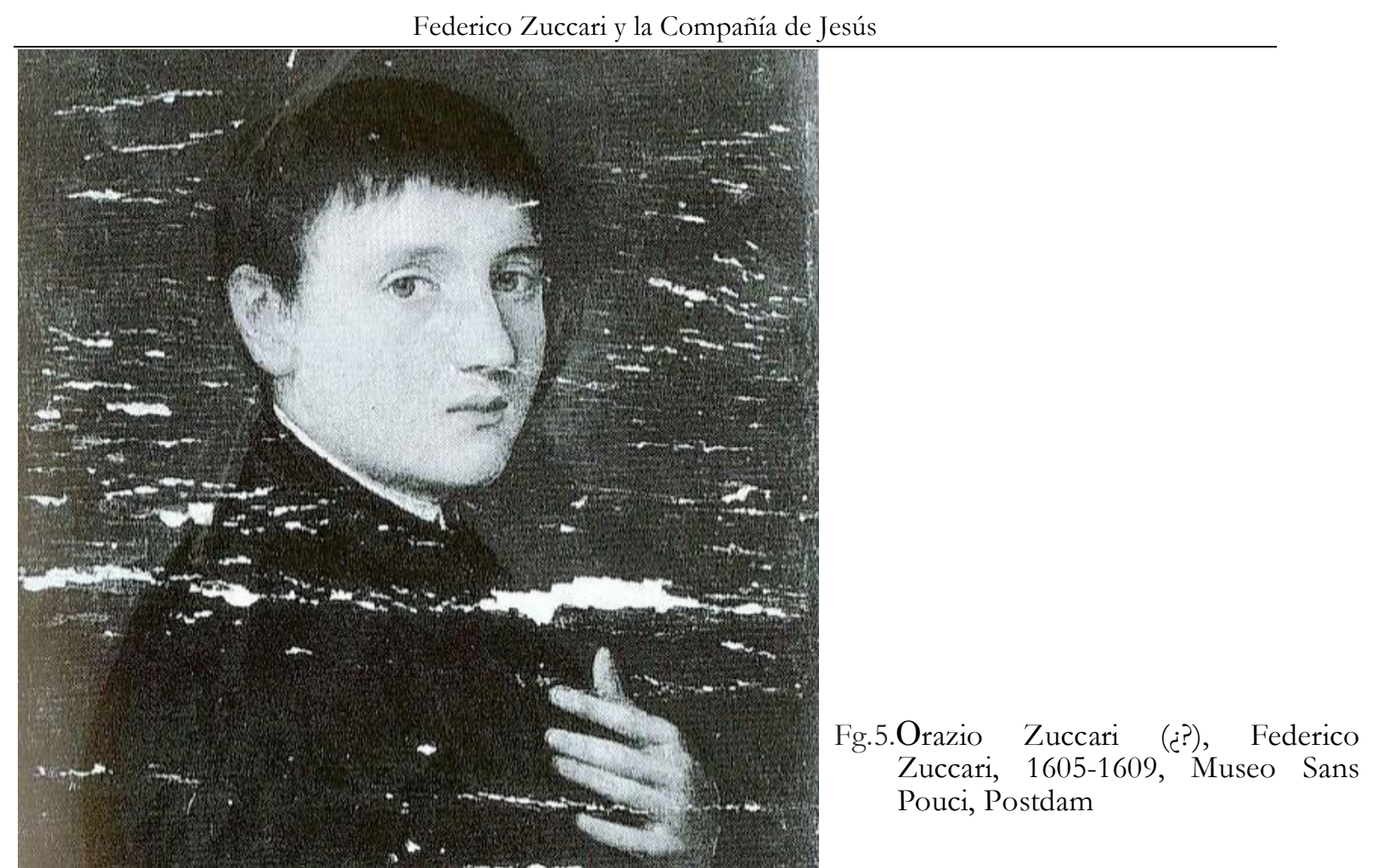

planes de mayor envergadura para su futuro. Las motivaciones sociales estaba, por lo tanto, en la base de su decisión cuando envió a su tercer hijo varón, Orazio, al noviciado romano de San Andrea de Montecavallo en el año 1605. Sin embargo, los planes que el artista había barruntado para este hijo jamás se cumplieron: Orazio Zuccari falleció, después de una larga enfermedad, el día de Navidad de 1619, con 34 años, sin haber tomado los últimos votos en la Compañía de Jesús, tal y como se desprende de los datos inéditos localizados en el Archivio Romano Societatis Iesu de Roma.

Federico Zuccari jamás olvidó el camino emprendido por su hijo junto a los jesuitas y posiblemente le retrató, justo después de su ingreso en la Compañía, para recordar siempre este acontecimiento tan dichoso. A este respecto, la atribución a Federico Zuccari de una pequeña tabla en el primer inventario de cuadros de la familia Giustiniani, realizado en 1618, proporciona noticias muy exiguas ${ }^{40}$ que nos han puesto sobre la pista del paradero de un retrato que podría identificarse con Orazio y que, a día de hoy, se conserva en los depósitos del Museo Sanssouci, de Postdam. El paradero de la obra, rastreado a partir de la exposición dedicada a la colección de la familia Giustiniani en el año 2001, nos ha permitido comparar el lienzo con los retratos de los varones de la familia Zuccari, a partir de las pinturas al fresco que el pater familias realizó de su prole en la residencia de Via Gregoriana. La vestimenta del retratado, un hábito o levitón negro, coincide con el utilizado por los miembros de la Compañía de Jesús en Europa durante la Edad Moderna, un dato que permite fechar la tabla,

${ }^{40} \mathrm{El}$ inventario señala: [...] un quadretto picciolo con una testina ritratto di Federico Zuccari (fatto dal medesimo nel ritorno d'Inghilterra) incollato in tavola di grandezza di un palmo e mezzo in circa con cornice negra [...].Cfr., DANESI

SQUARZINA D., «La collezione Giustiniani, Benedetto, Vincenzo, Andrea, nostri contemporanei » en el catálogo de la exposición, Caravaggio e i Giustiniani: Toccar con mano una collezione del Seicento, ed. Electa, 2001, pp.1745, en especial p.41. La profesora Silvia Danesi Squarzina identificó la pintura de uno de los hijos varones de Federico Zuccari a partir de una primera confrontación con los retratos familiares realizados por el pintor al fresco para la decoración en su residencia romana de via Gregoriana, pero no planteó como hipótesis la posibilidad de que se tratara del vástago jesuita. La pintura se conserva en la actualidad en el Museo Sanssouci de Potsdam (Alemania). 
entre 1605, el año en el que Orazio ingresó en el noviciado, y julio de 1609, fecha de fallecimiento del pintor. ${ }^{41}$

La entrada de este hijo en la Compañía favoreció que ésta se convirtiera en la depositaria de los secretos más íntimos de Federico Zuccari durante la última etapa de su vida, olvidado por todos y rechazado por aquellos que preferían las novedades pictóricas de los artistas más jóvenes, aquellos que jugarían un papel relevante, años más tarde, en la escuela barroca de pintura. Los jesuitas, generosos con el pintor que había participado en la decoración de las iglesias de Santa Maria dell'Anunziata o Il Gesù en Roma, le acogieron temporalmente en las diferentes residencias que tenían en ciudades como Bolonia o Parma, e incluso le encargaron diferentes obras.

Las cartas que remitió a su círculo de amigos romano en este periodo recogen su accidentado periplo por el norte de Italia y transmiten información acerca de los avatares de los últimos viajes, los homenajes y los reconocimientos que recibió por parte del gobierno de la República de Venecia o de Vincenzo Gonzaga, Duque de Mantua. El artista silenció, en cambio, otros agravios, aquellos recibidos por Carlo Emanuele I, duque de Saboya, o el aristócrata Ulisse Bentivoglio así como por parte de otros representantes de las clases sociales más altas del norte de la península italiana, los mismos que rechazaron su pintura y expresaron su predilección por las nuevas corrientes artísticas. ${ }^{42}$

Federico Zuccari trató de olvidar estas humillaciones aceptando pequeños encar-gos por parte de la Compañía de Jesús en una serie de pequeños núcleos urbanos alejados de Roma, aquellos en los que, poco a poco, los jesuitas estaban instalándose para extender su poder en el ámbito religioso, cultural, social, e incluso político. Una de sus intervenciones más celebradas fue seguramente la imagen de San Pablo realizada en la iglesia de los Santos Mártires, la primera iglesia fundada por los jesuitas en Turín, parroquia que estaba llamada a ejercer una importante influencia en el devenir religioso, político y cultural de la localidad. La historiografía ha barajado la posibilidad de que no fuera el único encargo de la Compañía en la ciudad ${ }^{43}$ dado que la institución buscó denodadamente el esfuerzo de todos para dar a conocer la vida, obras y milagros de los primeros jesuitas, e incentivar los procesos de beatificación y canonización de sus primeros integrantes. Para alcanzar tal propósito, la institución necesitaba divulgar los episodios más significativos de su biografía a través de la imágenes codificadas que reprodujesen fielmente sus aportaciones al apostolado de la Iglesia. $^{44}$

41 Véase la reproducción de la obra en el aparato de imágenes.

42 Nos referimos a Il passaggio per l'Italia y la Dimora di Parma, opúsculos muy breves que reúnen relaciones o cartas abiertas del pintor dirigidas a sus amigos en los que describió las peripecias de sus últimos años. Cfr., ZUCCARI F., Diporto per l'Italia. All'IIlustre et Eccellente Sig.r Pierleone Casella, [Torino, 6 Febbraio 1606], Bologna, 1608; Diporto per l'italia. Al Molto Illustre et Eccelente Sig. $r$ Cavalliero Gio.Bologna Scultore, [Torino, 18 Aprile 1606, ], Bologna, 1608; Diporto per l'Italia. Al Molto Illustre et Eccellente Sig. Federico Barocci, [Torino 30 Maggio 1606], Bologna, 1608. Otra serie de cartas abiertas fueron enviadas desde Ferrara, pero fueron publicadas en Bolonia en el año1609.

43 Véase la reproducción de la obra en ACIDINI LUCHINAT C., op.cit., 1997, vol. II, p.257. La autora alude también al testimonio del jesuita Emanuele Tesauro, que alabó en una de sus obras la pintura de San Pablo de Federico Zuccari. Un mayor número de obras atribuidas a Federico Zuccari en Turín y sus alrededores fueron descritas por BAUDI DE VESME.A.,

«L'arte negli stati sabaudi », en Atti della Società Piemontese di Archeologia e Belle Arti, vol. 14, 1932, pp.550-551 (reed. «L'arte in Piemonte dal XVI al XVII secolo», en Società Piemontese di Archeologia e Belle Arti, vol. I, 1963). El tema está pendiente de un estudio más específico.

${ }^{44}$ Es posible que FedericoZuccari conociese, entre otras, la obra realizada por el rector de la Basílica de Loreto, ORAZIO

TORSELLINI, que describió la biografía de San Francisco Javier en 1596. Véase Horatii Tursellini e Societate Iesu de vita Francisci Xaverii qui primus e Societate Iesu in India, et Iaponia evangelium invexit. Roma, 1596. Este tipo de publicaciones se convirtieron en la fuente principal de información para los primeros artistas que se ocuparon de divulgar la vida de los primeros jesuitas. 


\section{Federico Zuccari y la Compañía de Jesús}
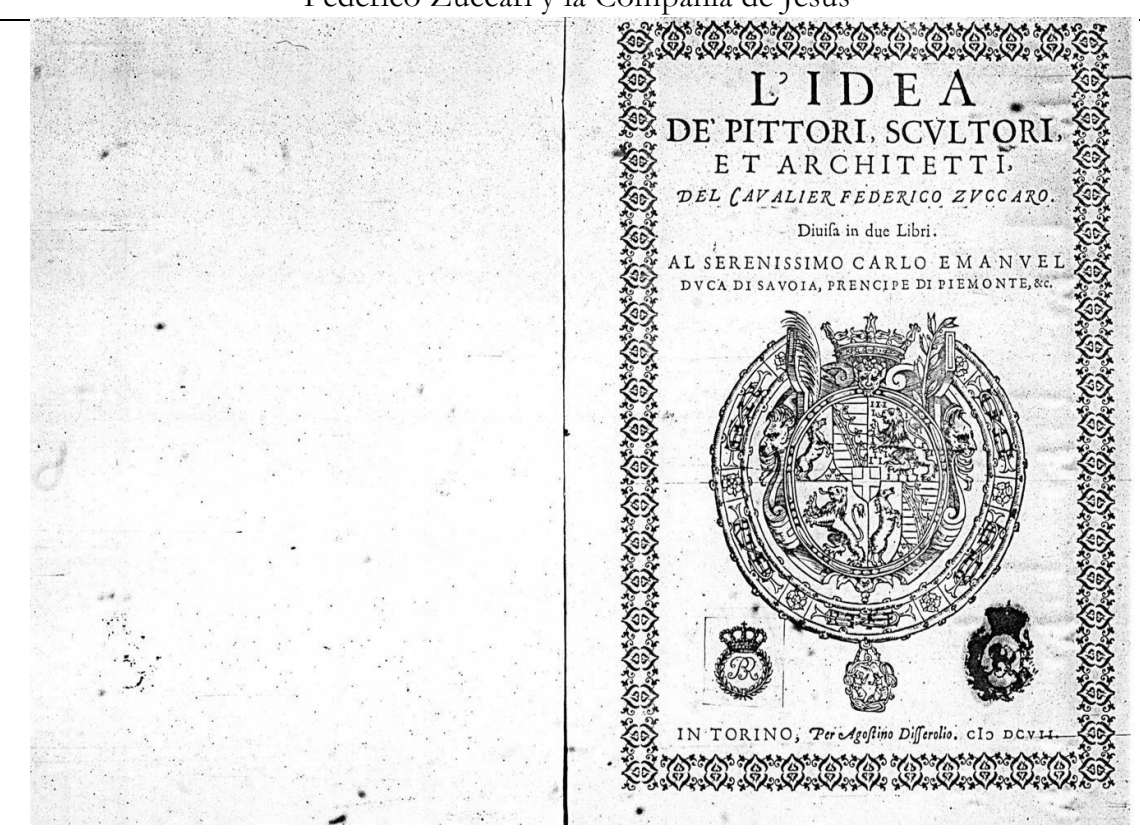

Fig.6. Portada de L'idea de'pittori, scultori ed architetti, Federico Zuccari, Turin, 1608

El periplo de Federico le llevó a recalar también en Parma. Los jesuitas fueron, en este sentido, los únicos que le reclamaron como artista en la localidad, dado que los hombres más notables de la iglesia rechazaron la propuesta de Zuccari de pintar el coro del conjunto catedralicio y completar, de este modo, el programa iconográfico ideado por Antonio da Correggio, todavía inacabado. La iglesia de San Roque, erigida por la Compañía de Jesús, le encargó pintar un Cristo atado a la columna, cuyo paradero se desconoce a día de hoy, dado que la iglesia fue destruida a mediados del siglo XVII. ${ }^{45} \mathrm{La}$ misma suerte ha corrido otro de los cuadros ideados por Federico Zuccari para una cofradía, dependiente de la Compañía, en la ciudad de Parma. En este caso se trataba de una composición con la representación de La Inmaculada Concepción que, a tenor de los numerosos epigramas en lengua latina que Federico Zuccari divulgó entre sus amistades, gozó de una excelente acogida en el seno de la comunidad religiosa.

La iglesia de Santa Lucia de Bolonia, una de las primeras fundaciones de San Ignacio de Loyola en la península italiana, fue uno de los últimos lugares en el que Federico Zuccari se alojó durante su paso por la ciudad en el año 1608. El pintor donó a los jesuitas boloñeses un lienzo de grandes dimensiones con la representación de La vision de la Storta que estaba destinado a ocupar un emplazamiento de relieve en el altar mayor de la iglesia del noviciado en la misma localidad. ${ }^{46}$ Esta pintura, de la que se perdió el rastro a mediados del siglo XIX,

45 Las fuentes no se ponen de acuerdo, ni siquiera, en el soporte elegido por Federico Zuccari para la realización de esta obra. Véase la descripción de ZUCCARI F., op.cit.,1608, pp.3-4. El manuscrito del Padre Zappata sobre las iglesias de la ciudad describía, a mediados del siglo XVIII, la pintura de Federico Zuccari como un fresco: Extra sacellum, cernitur Christi flagellatio picta in muro.

46 Para la realización de esta obra Federico Zuccari probablemente utilizó la serie de grabados estampados por HYERONIMUS WIERIX, Vita P. Ignatii de Loyola, Amsterdam, 1561, fol. 13. Descartamos, en cambio, la utilización por parte del artista de una serie posterior, publicada en 1610 por el PADRE RIBADENEYRA con el título Vita Beati Patris Ignatii Loyolae. Para una edición moderna de los grabados del jesuita véase La vida de San Ignacio en imágenes, ed. facsímil, Granada, 1992. En anteriores estudios realizados acerca de la pintura Visión de San Ignacio de Federico Zuccari no se ha utilizado como fuente la serie grabada por Wierix. Para ésta cuestión véase NAVARRETE PRIETO B., op.cit.,1998, pp.35-36. Zuccari acentuó en su descripción la presencia de los 
ha sido recientemente identificada en la Pinacoteca Nacional de Bolonia por Stefano Tumidei. ${ }^{47}$ Desde nuestro punto de vista se trata de la contribución pictórica más original e interesante del artista a la Compañía de Jesús durante esta última etapa. A este respecto, conviene recodar que este episodio de la vida del fundador guipuzcoano comenzó a divulgarse solo después de la beatificación de San Ignacio en el año 1610, y existen muy pocas imágenes, como la realizada por Zuccari, que recogen esta iconografía con anterioridad a esta fecha.

Esta contribución se convirtió en una de las últimas pinturas de Federico Zuccari, quien falleció de forma repentina durante su viaje de regreso a Roma, a su paso por la ciudad de Ancona, a mediados del mes de julio de 1609. Esta fecha puso punto final a una agitada trayectoria personal y profesional, que se vio notablemente beneficiada por los ventajosos contactos que el pintor estableció con la Compañía de Jesús, tal y como hemos descrito en este estudio.

ángeles, introduciendo una variante a la propuesta de Wierix. Para las imágenes de la serie véase MAUQUOYHNEDRICKX M., Les estampes des Wierix, Bruxelles, 1979, vol. II, 1038-1050

47 Véase TUMIDEI S., «Federico Zuccari e i gesuiti bolognesi: la pala del 1608 », en Dedicato alla memoria di Stefano Tumidei, Trento, ed. Temi, 2008, pp. 93-105 